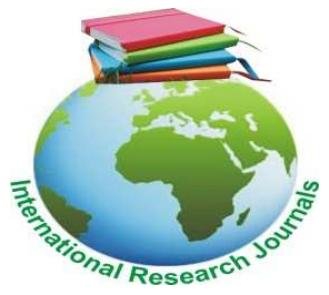

Educational Research (ISSN: 2141-5161) Vol. 9(2) pp. 021-034, March, 2018

Available online@ http://www.interesjournals.org/ER

DOI: http:/dx.doi.org/10.14303/er.2018.018

Copyright (C) 2018 International Research Journals

Full Length Research Paper

\title{
Awareness of corrosion importance among engineering undergraduates in the United Arab Emirates
}

\author{
${ }^{1 *} \mathrm{Dr}$. Hwee Ling Lim and ${ }^{2} \mathrm{Dr}$. Ebru Gunister \\ ${ }^{1}$ Petroleum Institute (a part of Khalifa University of Science and Technology), College of Arts and Science, P.O. Box \\ 2533, Sas Al Nakheel Campus, Abu Dhabi, United Arab Emirates. \\ ${ }^{2}$ Petroleum Institute (a part of Khalifa University of Science and Technology),Mechanical Engineering Department, \\ College of Engineering, P.O. Box 2533, Sas Al Nakheel Campus, Abu Dhabi, United Arab Emirates \\ ${ }^{*}$ Corresponding author's Email: hlim@pi.ac.ae
}

\begin{abstract}
Engineers are ethically responsible for managing corrosion. While corrosion control methods are applied in the industry, it is as important to educate engineering undergraduates on aspects of corrosion and its management. However, there is little research on corrosion awareness among undergraduate students. This qualitative study examined engineering undergraduates' awareness of corrosion importance in the petroleum industry. 20 sophomore and 44 senior undergraduates were interviewed on their preferred level of corrosion instruction; understanding of corrosion importance in engineering work; and perceptions of own knowledge and ability to apply corrosion concepts in design. Also, a quiz on I corrosion concepts was administered. It found that most participants preferred to study corrosion as an elective at junior, senior levels. Compared to sophomores, more seniors reported awareness of corrosion importance in engineering work; had higher positive self-perceptions of their knowledge of corrosion and application ability that were consistent with their higher quiz scores. Interestingly, sophomore and senior participants were more confident of their ability to apply corrosion concepts in design than having theoretical knowledge in corrosion. The findings indicated that undergraduates need to develop greater awareness of corrosion importance in engineering work. The recommendations provided could be used to improve corrosion engineering education pedagogy.
\end{abstract}

Keywords: Competence; Corrosion; Engineering; Student perception; Undergraduate research

\section{INTRODUCTION}

Corrosion Science is a multidisciplinary field that aims to understand the mechanisms behind materials degradation or corrosion. Corrosion Engineering involves the application of corrosion science principles to minimize or prevent corrosion in engineering design practice (Ahmad, 2006). There is a strong synergistic relationship between Corrosion Science and Corrosion Engineering in that a sound understanding of the former forms the basis for the competent practice of corrosion engineering that avoids significant financial losses and safety problems, particularly in the petroleum industry. Engineers are ethically and legally responsible for managing corrosion and its associated risks. Since many corrosion control methods are applied in the petroleum industry, it is important to educate engineering undergraduates on aspects of corrosion and its management relevant to their discipline.

The Arabian Gulf is a politically and economically strategic region encompassing major oil/gas producing countries such as the Gulf Cooperation Council (GCC) states, Iran and Iraq. Although their petroleum reserves dwarf those in most other regions in terms of quality and quantity, these countries faced recent unprecedented challenges such as prolonged low oil prices; and reduced oil/gas demand due to competition from unconventional energy sources (US shale oil/gas) and worldwide economic slowdown at 2.9\% growth (2016 forecast) (Botes, 2015; Ernst and Young Limited, 2016). As the average annual OPEC crude oil price fell from a high of $\$ 109 / \mathrm{bbl}$ (2012) to $\$ 51 / \mathrm{bbl}$ (2017 estimate) (The Statistics 
Portal, 2017), petroleum companies struggle to simultaneously reduce costs yet improve performance and maintain asset integrity (Donati, 2016). A 2016 National Association of Corrosion Engineers (NACE) study estimated the global cost of corrosion as $\$ 2.5$ trillion; equivalent to $3.4 \%$ of a country's Gross Domestic Product (GDP) (NACE, 2016). The study found that implementing corrosion prevention best practices could reduce costs by $15 \%-35 \%$ ( $\$ 375$ to $\$ 875$ billion). It also identified the need for more corrosion management professionals given the upcoming big crew change in the next decade.

There are only a few established universities in the Arabian Gulf that award solely engineering degrees. They include King Fahd University of Petroleum and Minerals; and King Abdullah University of Science and Technology (Kingdom of Saudi Arabia); Petroleum Institute (United Arab Emirates, UAE); Texas AandM University at Qatar (State of Qatar). Graduates from these engineering universities typically remain in the region throughout their careers. They form a vital group of professionals who contribute to the growth of the Middle East's petroleum industry with their engineering skills, knowledge, and problem-solving abilities. Although corrosion is an inevitable natural process, its economic, environmental and societal consequences could be minimized and managed by an engineering workforce that is well educated in corrosion fundamentals and management. However, there is scarce research on the concept of awareness of corrosion importance among students at its developmental stage in higher education.

This study aims to assess engineering undergraduates' awareness of corrosion importance in the context of the petroleum industry. Specifically, the project (a) compares awareness of corrosion importance between senior and sophomore undergraduates from a major university in the UAE; and (b) provides recommendations for enhancing corrosion awareness among engineering undergraduates. The findings could improve current engineering education pedagogy and enhance awareness of corrosion importance among engineering undergraduates that would lower costs and risks associated with corrosion; enable compliance with regulatory requirements; help maintain asset integrity and the competitive edge of the petroleum industry in these economically challenging times.

\section{Literature review}

\section{Corrosion: Definition, causes and mechanisms}

Corrosion is the degradation of materials by chemical, biological and environmental processes (Ahmad, 2006). Corrosion in petroleum production involves three main mechanisms (Brondel et al., 1994):
- Electrochemical corrosion (galvanic; crevice; pitting).

- Chemical corrosion (reacting with $\mathrm{H}_{2} \mathrm{~S}$; polysulfides; sulfur; $\mathrm{CO}_{2}$; strong acids; concentrated brine; biological effects from generation of $\mathrm{H}_{2} \mathrm{~S}$ by sulfatereducing bacteria-SRB).

- Mechanical corrosion (cavitation; erosion; erosion corrosion; stress corrosion cracking that includes sulfide stress corrosion (SSC), chloride stress cracking (CSC), and corrosion fatigue.

To elaborate, in the presence of water, atmospheric oxygen can degrade many materials used in the oil/gas industry. Common salt $(\mathrm{NaCl})$ dissolved in water is particularly problematic because the chloride ion breaks down the protective layers on many metals. The presence of hydrogen sulfide $\left(\mathrm{H}_{2} \mathrm{~S}\right)$ and carbon dioxide $\left(\mathrm{CO}_{2}\right)$ can further degrade materials used in the oil/gas industry since both compounds are commonly encountered in industry operations. When $\mathrm{CO}_{2}$ dissolves in water, it forms carbonic acid that lowers the $\mathrm{pH}$ of water thus increasing its corrosiveness. $\mathrm{H}_{2} \mathrm{~S}$ is highly corrosive and if present in petroleum wells, can cause serious cracking problems when it comes in contact with high-strength steel that is under stress (Sastri, 2015).

\section{Financial impact of corrosion: Worldwide and the GCC states}

The 2016 global cost of corrosion was estimated by NACE at $\$ 2.5$ trillion; equivalent to $3.4 \%$ of a country's GDP (NACE, 2016). Despite efforts by the GCC states to diversify their economies and expand non-oil sector contribution to the GDP in face of oil price volatility, the hydrocarbon sector remains a significant part of their economies, contributing an average of $28.9 \%$ to the states' GDP in 2015 (Ernst and Young Limited, 2016). Hence, the cost of corrosion is significant to the GCC states given their large petroleum industries. The latest corrosion cost figures for the GCC states are not available other than 2011 estimates. The UAE annual cost of corrosion is estimated at $\$ 14$ billion (2011) i.e. $5.2 \%$ of the country's GDP over three years (2009-2011) (Table 1). Among the GCC states, the UAE incurs the second highest cost of corrosion after Saudi Arabia (\$25 billion) followed by Qatar ( $\$ 8$ billion) (Al Hashem, 2011).

In the petroleum industry, about $25 \%$ of failures are corrosion-related (Kermani and Harrop, 1996) leading to costs in the following areas:

Degradation of the pipeline infrastructure for transportation and storage of natural gas, crude oil, and refined petroleum products. For instance, the 2013 Sinopec gas pipeline explosion was caused by the ignition of vapors produced from oil leaking from a corroded underground pipeline that resulted in a loss of $\$ 124.9$ million (NACE, 2017). 
Table 1: Annual cost of corrosion for GCC states, 2011 estimate.

\begin{tabular}{lc}
\hline GCC States & US\$ billion \\
\hline Kingdom of Saudi Arabia & 24.8 \\
United Arab Emirates & 14.3 \\
State of Qatar & 7.8 \\
State of Kuwait & 6.5 \\
Sultanate of Oman & 3.3 \\
Kingdom of Bahrain & 1.3 \\
\hline
\end{tabular}

- Corrosion of the assets involved in the crude oil production. In 2006, following a major oil spill in Alaska's Prudhoe Bay, pipeline inspection by BP engineers found corrosion losses of $70 \%$ to $81 \%$ of pipe walls. The cost of replacing the pipelines and installation of anti-corrosion systems reached $\$ 500$ million (The Guardian, 2011).

Extensive chemical treatments required to maintain asset integrity. The Thamama Zone $\mathrm{C}$ gas gathering system in Bab Field (Abu Dhabi) commissioned in 1984, faced problems of excessive internal and external corrosion of trunklines, and gas leaks from external corrosion. The long term solution implemented was a major replacement of the whole system (Morsi and Al Key, 1993).

- Loss of production due to downtime. In 2013, the Cormorant Alpha in the UK North Sea was shut down after an oil leak incident. The shutdown affected the entire Brent pipeline system and lost production was estimated at $\$ 10$ million/day (at $\$ 110 /$ barrel, 2013) (Offshore Energy Today, 2013).

\section{Health, safety and environment impact of corrosion}

The effect of corrosion on health, safety, and environment (HSE) is as important as its financial impact. In the petroleum industry, corrosion affects asset integrity and reliability. For instance, pipeline corrosion can cause leaks resulting in the discharge of flammable liquid and gases which can pollute the environment and lead to accidents and human casualties.

Notable incidents caused by corrosion in the GCC region include: Rawdhatain, Kuwait (January 31, 2002) when a pipeline leak due to corrosion resulted in a major explosion that destroyed three main facilities, killed four and injured 17. Also, Umm Said, Qatar (April 3, 1977) when a tank containing 236,000 bbl of refrigerated propane at $45^{\circ} \mathrm{F}$ failed at a weld that was corroded by SRB that remained in the tank after hydro testing with seawater. The propane liquid wave ignited a nearby butane tank and the resulting fire took eight days to extinguish (Abduh, 2011).

\section{Code of ethics and regulatory compliance}

The need to reduce financial and environmental consequences of corrosion failure makes it an imperative to develop awareness of corrosion importance in engineering students. The need to build this awareness is also motivated by professional ethical considerations and compliance with regulatory requirements. Risk is present in all engineering projects as a result of uncertainty and inherent hazards (Engineering Council, 2011). Engineers conduct risk management for projects to identify likelihood of hazards and limit or eliminate associated risks. Corrosion is a hazard and presents risks that engineers are ethically bound to manage. Codes of ethics from various engineering professional societies and accreditation boards (ASME, ICE, IEEE, ABET, etc.) adopt the fundamental canons that engineers shall hold paramount the safety, health, and welfare of the public; perform services only in the areas of their competence; conduct themselves honorably, responsibly, ethically, and lawfully to enhance the honor, reputation, and usefulness of the profession (NSPE, 2016).

To ensure a high standard of safety, countries have ratified legislation for regulating risks from major industrial hazards that impact engineering risk management practices. For instance, the US Department of Transportation (in US Code of Federal Regulations-CFR, Title 49, Subtitle B, Part 192, Subpart I) defines the requirements for corrosion control, including internal and external corrosion control for buried and submerged pipelines, atmospheric corrosion control, remedial measures, direct assessment, and corrosion control records (Fessler, 2008). Unlike CFR Title 49, UK legislation does not specifically state a requirement to manage corrosion. Instead, the emphasis is placed on the duty holder to ensure system integrity and safe operation of facilities. The UK legislation governing activities in processing facilities for offshore installations includes: Health and Safety at Work etc. Act 1974 (HSW Act); Offshore Installations (Safety Case) Regulations (SI 1992/2885) (SCR); and Offshore Installations (Prevention of Fire and Explosion, and Emergency Response) 
024 Educ. Res.

Regulations 1995 (SI 1995/743) (PFEER) (Capcis Limited, 2001).

In Abu Dhabi (UAE), the Executive Council of Abu Dhabi Emirate approved the Abu Dhabi Emirate Environment, Health and Safety (EHS) Policy in 2006 and the Environment, Health and Safety Management System Regulatory Framework (v. 1.2) was implemented in 2009. This legislation requires all companies to have an EHS emergency plan that is approved by the Abu Dhabi Environment, Health and Safety Centre. There would also be inspection, auditing, investigation of EHS incidents, and monitoring of EHS performance to ensure proper implementation of plans (Department of Municipality Affairs, 2014).

Besides state legislation, companies may set internal standards for regulating safe operations. For instance, the Abu Dhabi National Oil Company (ADNOC), which functions as the de facto HSE regulatory body for the petroleum industry in Abu Dhabi, adopted a centralized framework of operational standards known as the ADNOC Codes of Practice (COP). The COP refers to UAE Laws and Regulations, standards in place in the ADNOC Group Companies, and standards used by the international petroleum industry (ADNOC, 2011). A number of international standards development organizations also play a role in developing standards that guide corrosion management, testing, and pipeline integrity such as NACE International (SP0169-2007; SP0106-2006); American Society of Mechanical Engineers (ASME B31.8S; ASME B31.4); and American Petroleum Institute (API 1160; API 579) (Fessler, 2008).

\section{Developing awareness of corrosion importance among engineering undergraduates}

Although corrosion is a natural process that cannot be eliminated, its associated costs can be minimized by a technical workforce well educated and trained in Corrosion Science and Materials Engineering that can contribute to developing new materials and protection technologies that are vital to efficient petroleum production. However, the petroleum industry is losing its corrosion experts due to the big crew change; with fewer new graduates expected to replace them (Hays, 2015). For instance, in the university where this research was conducted, enrollment in the senior level Corrosion Engineering course has declined steadily. Initially, 100 students enrolled in the elective from Fall 2010 to Spring 2014 (4 academic years) but the numbers declined to 45 students from Fall 2014 to Spring 2017 (3 academic years). This trend could be attributed to competition from other/new electives and signals the availability of fewer graduates specializing in corrosion engineering who will be needed to deal with the worldwide aging infrastructure.
Ismail et al. (2008) examined the awareness of professional engineers in Malaysia towards reinforcement corrosion protection and prevention. It surveyed engineers and architects from the construction industry on their awareness of (a) types and sources of corrosion; (b) corrosion prevention and repair methods for reinforced concrete structures. It found that most participants were more familiar with general/pitting corrosion types due to carbonation and chloride attack than bacterial/dissimilar metal corrosion; and sources such as air salinity; air humidity; and bacterial attack. Also, more participants reported experience with conventional prevention method of surface treatment (protective coating, patch repair) than solar energy systems or repair methods such as cathodic protection and prevention, chloride removal, and realkalization. It concluded that awareness of common methods of corrosion management was satisfactory but practicing engineers' awareness of newer technologies/methods in corrosion control need to be enhanced.

When practicing engineers demonstrated a less than satisfactory awareness of corrosion management methods, it becomes necessary to examine how corrosion is taught in higher education. Lim (2012) examined the quality of corrosion education in engineering programs of four UAE universities from the perspectives of academia and industry participants. Respondents held the consensus view that there was insufficient fundamental knowledge of corrosion engineering among undergraduates due to the limited scope of corrosion content taught in the curriculum and the elective status of corrosion courses. Also, industry participants were highly critical of young engineers' superficial understanding of corrosion in real-life design contexts.

The study reported here did not replicate Lim (2012) but extended the work by focusing on awareness of corrosion importance from the students' perspective. Together with data from Lim (2012), this study would enable a richer understanding of the state of corrosion education and contribute towards extrapolation of findings beyond the UAE to the wider Arabian Gulf region.

\section{METHODS}

\section{Research context, constructs and assumptions}

The research context is a major engineering university located in Abu Dhabi (UAE). It is accredited by the Accreditation Board for Engineering and Technology $(A B E T)$ and produces engineering baccalaureate graduates for employment in the UAE oil sector (Ozturk et al., 2015). It offers degrees (Bachelor, Master, and PhD) only in Chemical, Mechanical, Electrical, and 
Table 2: Constructs and measures of the research study.

\begin{tabular}{|c|c|}
\hline Constructs & Operationalized measures (Coverage of questions) \\
\hline \multirow[t]{6}{*}{$\begin{array}{l}\text { Preferred level of corrosion } \\
\text { instruction }\end{array}$} & $\begin{array}{l}\text { Preferred level to study corrosion (freshman, sophomore, junior, } \\
\text { senior, postgrad levels) }\end{array}$ \\
\hline & Preferred corrosion course status (elective vs. required) \\
\hline & Current course load for accommodating required corrosion course \\
\hline & Choice of technical elective CHEG 416 (Corrosion Engineering) \\
\hline & Amount of lectures sufficient to learn about corrosion \\
\hline & Importance of other engineering topics compared to corrosion \\
\hline \multirow{2}{*}{$\begin{array}{l}\text { Understanding of corrosion } \\
\text { importance in engineering work }\end{array}$} & Engineering majors that require corrosion knowledge \\
\hline & Types of practicing engineers who require corrosion knowledge \\
\hline \multirow{3}{*}{$\begin{array}{l}\text { Competence in corrosion: } \\
\text { Knowledge in corrosion \& } \\
\text { ability to apply corrosion } \\
\text { concepts in design }\end{array}$} & $\begin{array}{l}\text { Self-perception: having sufficient fundamental knowledge of } \\
\text { corrosion engineering }\end{array}$ \\
\hline & $\begin{array}{l}\text { Self-perception: ability to understand corrosion importance in } \\
\text { engineering design }\end{array}$ \\
\hline & $\begin{array}{l}\text { Quiz on corrosion fundamental concepts (questions based on } 3 \\
\text { learning objectives }{ }^{*} \text { ) }\end{array}$ \\
\hline
\end{tabular}

*NOTE- Quiz Learning Objectives (LO): The students should be able to demonstrate knowledge and understanding of

LO 1: corrosion mechanism and forms of corrosion in different environments.

LO 2: importance of corrosion in engineering design for petroleum industry.

LO 3: identifying, monitoring, prevention and mitigation of corrosion.

Petroleum engineering, and Geosciences. This study aims to assess engineering undergraduates' awareness of corrosion importance. Table 2 lists the constructs and their operationalized measures as coverage of questions posed to participants.

The following assumptions are held for the constructs:

Assumption 1: Participants who regard corrosion as important would prefer a required corrosion engineering course and disagree with the statements that a few lectures on corrosion are needed and other engineering topics are more important than corrosion.

Assumption 2: Participants who regard corrosion as important would select all majors or at least Chemical, Mechanical and Petroleum engineering majors as requiring corrosion knowledge and disagree that only corrosion engineers need to know about corrosion.

Assumption 3: More seniors would self-report having sufficient fundamental knowledge of corrosion and understanding of corrosion in engineering design (application), and score higher in the quiz than sophomores.

\section{Sampling}

The sample was male Emirati and expatriate undergraduates (sophomores and seniors) from an engineering university in the UAE. The inclusion of only male participants needed some explanation: the university is gender segregated with separate campuses for each gender. Since the authors' research assistants were male, data collection via face-to-face interviews could only be conducted with male participants due to cultural restrictions regarding interactions between genders. The total sample was 64 (sophomore 20; senior 44).

The sophomore sample size was not equivalent to the senior sample as the researchers encountered limited availability and access to the sophomores. The participant profile indicated that most were Emiratis, enrolled in Mechanical, Petroleum and Chemical Engineering programs (Table 3). 6.8\% $(n=3)$ senior participants had completed CHEG416 (Corrosion Engineering) which is a technical elective that aims to provide engineers with the tools required to identify, assess, and control corrosion and oxidation in the petroleum and chemical processing industries.

The course pre-requisites till Fall 2016 were completion of Chem102 (General Chemistry II) and senior standing (90 credit hours completed) or GPA of 3.0 and above. As Chem102 is compulsory only for Geoscience, Chemical and Petroleum engineering students, CHEG416 was not available for Mechanical and Electrical engineering students at that time. In Spring 2017, the pre-requisites were reduced to Chem101 
Table 3: Respondents' demographics

\begin{tabular}{llcc}
\hline Demographics & Senior $^{\star}$ & Sophomore $^{*}$ \\
\hline Nationality & Emirati & $88.6 \%$ & $70.0 \%$ \\
Program & Mechanical engineering & $40.9 \%$ & $35.0 \%$ \\
& Petroleum engineering & $36.4 \%$ & $30.0 \%$ \\
& Chemical engineering & $15.9 \%$ & $25.0 \%$ \\
& Electrical engineering & $4.5 \%$ & $5.0 \%$ \\
& Geosciences & $2.3 \%$ & $5.0 \%$ \\
CHEG416 & Completed CHEG416 Corrosion Engineering & $6.8 \%$ & $0.0 \%$ \\
& *\% based on Senior $(n=44)$, Sophomore $(n=20)$. & \\
\hline
\end{tabular}

(General Chemistry I) and senior standing hence opening CHEG416 to all programs.

\section{Instrument and data analysis}

As the project adopted a qualitative research framework, individual and focus group interviews were held using an interview questionnaire. Parts $A-C$ in the questionnaire had closed questions on demographics and the constructs while Part $D$ had open-ended questions that elicited elaborations on choices made in earlier questions and suggestions for raising corrosions awareness. Audiorecording of the interviews started at Part D. Two primary methods for gathering information about people's beliefs or behaviors are surveys and interviews. Surveys are less time consuming and when limited to closed questions, the quantitative data can be analyzed quickly. However, interviews can obtain detailed information from a small group of participants via probing questions and capture verbal/non-verbal cues (Pickard, 2007; Driscoll, 2011). In this research, face-to-face interviews were used as the sample size was not large and elaboration of response choices was required. Interviews can be classified into focus group and individual interviews. Focus group interviews provide direct evidence of similarities or differences in participants' responses, while individual interviews can only reach such conclusions after comparing each interviewee's response. However, individual interviews offer more control to the interviewer and participants have more time to express their views. On the other hand, focus groups can generate more productive discussions with more diverse ideas when participants have more control of the interactions (Morgan, 1997). Both face-to-face focus groups and individual interviews were used as the advantages of one method compensated for the disadvantages of the other.

46 individual and 6 focus group interviews (3 participants per group) were conducted. Given the small sample size, quantitative data gathered from closed questions are presented as descriptive statistics. For attitudinal closed questions, a 5-point scale was used ranging from 5-Strongly Agree to 2-Strongly Disagree and 1-Not sure/Don't know for responses to statements. Qualitative data analysis was inductive and involved the following: transcription of interview audio-recordings; identification of themes that emerged from the data; creation of coding scheme with frequency of theme occurrence assumed to indicate importance of the idea; checking inter-rater reliability of coders; coding of complete datasets; and interpretation of findings based on the research questions. The qualitative results are presented as themes and verbatim quotes included in places to more accurately reflect the voices of participants. The original language use was retained in the quotes.

\section{Ethical issues}

Ethics in research refers to the obligation and accountability of the researcher to respect the rights, dignity and safety of participants and society. The main ethical issues in this project were participant protection, confidentiality, and informed consent. This research did not pose risks of placing participants in physical danger or causing emotional/mental distress. Confidentiality of identity was ensured by not gathering real names of participants, removing identifying details, using codes to replace actual names in interview transcription and publications. For instance, the codes "Sopm\#1" and "Senior\#1" refer to sophomore and senior participants, respectively. All participants read, understood and signed a consent form that included the project aims, assurance of confidentiality, consent to voluntary participation and audio-recording, and right to withdraw from participation without penalty.

\section{RESULTS AND DISCUSSION}

\section{Preferred level of corrosion instruction}

The construct preferred level of corrosion instruction was 
Table 4: Preferred level for studying corrosion

\begin{tabular}{lll}
\hline $\begin{array}{ll}\text { Q. At which level(s) should engineering students } \\
\text { study corrosion? Select all that apply.* }\end{array}$ & Senior & Sophomore \\
\hline Postgraduate & $9.1 \%$ & $10.7 \%$ \\
Senior & $\mathbf{2 9 . 1} \%$ & $\mathbf{3 2 . 1} \%$ \\
Junior & $\mathbf{4 5 . 5 \%}$ & $\mathbf{3 2 . 1} \%$ \\
Sophomore & $14.5 \%$ & $17.9 \%$ \\
Freshman & $1.8 \%$ & $7.1 \%$ \\
*\% based on total number of choices made for the 5 options: Senior choices \\
(55); Sophomore choices (28).
\end{tabular}

Table 5: Elective course preference reasons: Ranked by importance

\begin{tabular}{ll}
\hline Senior & Sophomore \\
\hline \begin{tabular}{ll} 
1. Corrosion not relevant to major. & 1. Corrosion not relevant to major. \\
2. Need freedom of choice of electives. & 2. Difficulty of course / Heavy course load. \\
2. Difficulty of course / Heavy course load. & \\
3. Lack of interest in corrosion. & \\
3. Corrosion covered in other courses & \\
\hline
\end{tabular}
\end{tabular}

measured by questions on preferred (a) level to study corrosion; (b) course status for a corrosion engineering course; and (c) amount of instruction. Table 4 shows that junior and senior levels were most preferred by senior $(74.1 \%)$ and sophomore $(64.2 \%)$ participants. It may be because at sophomore year, students complete basic science and engineering courses specific to their disciplines, such as General Chemistry I/II; Introduction to Modern Mechanical Engineering; and Principles of Chemical Engineering, that introduce corrosion principles and at its role in HSE considerations. This background is both assumed by instructors and needed by students to understand the more advanced principles such as corrosion mechanisms and application in engineering design that are taught in junior/senior courses such as Thermodynamics; Fluid Mechanics; Mechanics of Materials; Production Facilities; Corrosion Engineering; and Engineering Design Project I/II.

For course status, an elective corrosion engineering course was preferred by most senior (61.4\%) and sophomore $(65 \%)$ participants due to the main reasons: corrosion is not relevant to their major; difficulty of the course; and heavy course load (Table 5). More seniors $(59.1 \%)$ than sophomores $(50 \%)$ strongly agreed and agreed (SA and A) that their current course load is already too heavy to include a required corrosion course. It should be noted that the five degrees awarded by the university require 130 to 134 credits for graduation.
Similar reasons were given when participants explained why they did not enroll (seniors) or have no interest in enrolling (sophomore) in the technical elective CHEG416-Corrosion Engineering (Table 6). The top two reasons need clarification. The reason Not relevant to major (from sophomores) is interpreted as the view that corrosion is an inconsequential issue in their specific engineering discipline whereas Not a required course for major (from seniors) refers to the CHEG416 status as an elective rather than required course in their degree study plan. The sophomores' reason suggests that instructors could place more emphasis on the impact of corrosion in their course context and link it to future study of CHEG416. Also, in light of the fewer course prerequisites from Spring 2017 (explained earlier), the seniors' reason Not aware of course availability suggests that more publicity is needed to promote CHEG416 among students with senior credit standing.

For amount of corrosion instruction (Table 7), more sophomore than senior participants agreed (SA and A) that $A$ few lectures are sufficient to learn about corrosion (85\%); and other engineering topics are more important than corrosion $(70 \%)$. The findings suggest a need to emphasize more strongly the significant role that corrosion plays in the engineering process among sophomores.

Respondents who disagreed that other engineering topics are more important than corrosion gave the main 
028 Educ. Res.

Table 6: Reasons for not enrolling in CHEG416: Ranked by importance

\begin{tabular}{ll}
\hline Senior & Sophomore \\
\hline 1. Not a required course for major & 1. Not relevant to major \\
2. Difficulty of course & 2. Heavy course workload \\
3. Not aware of course availability & 3. Lack interest in course \\
3. Not relevant to major & \\
4. Time conflicts & \\
5. Less preferable elective compared to others & \\
6. Lack interest in course & \\
6. Heavy course workload & \\
\hline
\end{tabular}

Table 7: Preferred amount of corrosion instruction

\begin{tabular}{|c|c|c|c|c|c|c|}
\hline \multirow{2}{*}{$\begin{array}{l}\text { Q. To what extent do you agree } \\
\text { with the following statements? }\end{array}$} & \multicolumn{3}{|c|}{ Senior } & \multicolumn{3}{|c|}{ Sophomore } \\
\hline & SA\&A* & SD\&D & DK & SA\&A* & SD\&D & DK \\
\hline $\begin{array}{l}\text { A few lectures are sufficient to learn } \\
\text { about corrosion in engineering }\end{array}$ & $45.5 \%$ & $38.6 \%$ & $15.9 \%$ & $85.0 \%$ & $15.0 \%$ & $0.0 \%$ \\
\hline $\begin{array}{l}\text { Other engineering topics are more } \\
\text { important than corrosion }\end{array}$ & $50.0 \%$ & $36.4 \%$ & $13.6 \%$ & $70.0 \%$ & $25.0 \%$ & $5.0 \%$ \\
\hline
\end{tabular}

reasons: corrosion is relevant to most activities in the petroleum industry and all engineering topics are equally important. In contrast, participants who agreed mainly listed topics that they considered more important than corrosion:

\begin{abstract}
"There are many other engineering topics that are more important. If you look into chemical engineering itself, you will see that polymer engineering. In mechanical you will see mechanics or in petroleum you will see fluid properties." (Sopm\#4)

"Mass transfer and heat transfer, as a chemical engineering student these two engineering topics are far more important to me in the work field and for my understanding of chemical engineering which offers me greater benefit than corrosion courses." (Senior\#13)

"Because we work for [an oil company], it is all about crude oil for example, so polymers which is I think it more important than corrosion, maybe corrosion is important but someone should be responsible not all engineers." (Sopm\#2)
\end{abstract}

\section{Understanding importance of corrosion in engineering work}

The construct understanding of corrosion importance in engineering work was measured by questions on engineering majors that require corrosion knowledge; and types of practicing engineers who require corrosion knowledge. Table 8 shows that Chemical, Mechanical, and Petroleum engineering were selected as the main majors that require corrosion knowledge. Most participants disagreed (SD and D; seniors 72.7\%; sophomore 65\%) that only corrosion engineers need to know about corrosion. In the petroleum industry context, it was expected that these three disciplines were selected as they involve process/plant design; oil/gas exploration activities (rigs, wells); and development of on/offshore field production facilities in which corrosion is often a significant problem. However, it is interesting to note that few participants selected all majors, suggesting a strong demarcation of corrosion relevance between disciplines to exclude Electrical Engineering and Geosciences and a need to reinforce the interdisciplinary nature of corrosion in engineering students.

\section{Competence in corrosion}

Competence in corrosion is defined as having knowledge of corrosion and ability to apply corrosion concepts in design viz. besides mastering the fundamentals, another dimension of competence is the ability to apply theoretical knowledge in practice. The construct was first measured by questions on participants' self-perception of having (a) sufficient fundamental knowledge of corrosion engineering (theory); and (b) sufficient understanding of the importance of corrosion in engineering design (application). Then a quiz on fundamental corrosion concepts based on three learning objectives (LOs) was administered to participants. The quiz comprised 20 multiple-choice questions completed by participants without a specified time constraint (Appendix 1). The average quiz score presented here was obtained as a percent of correct answers for 20 questions based on 44 seniors and 20 sophomores. As participants may inflate or underestimate their self-perception of competence in 
Table 8: Majors requiring corrosion knowledge

\begin{tabular}{lcc}
\hline $\begin{array}{l}\text { Q. Which major(s) would require students to } \\
\text { know about corrosion? Select all that apply. }\end{array}$ & Senior & Sophomore \\
\hline All majors & $12.6 \%$ & $9.3 \%$ \\
Chemical engineering & $\mathbf{3 0 . 5 \%}$ & $\mathbf{3 4 . 9 \%}$ \\
Mechanical engineering & $\mathbf{2 4 . 2 \%}$ & $\mathbf{2 3 . 3} \%$ \\
Electrical engineering & $3.2 \%$ & $7.0 \%$ \\
Petroleum engineering & $\mathbf{2 4 . 2} \%$ & $\mathbf{1 8 . 6 \%}$ \\
Geosciences & $5.3 \%$ & $4.7 \%$ \\
Not sure & $0.0 \%$ & $2.3 \%$
\end{tabular}

*\% based on total number of choices made for the 7 options: Senior choices (95); Sophomore choices (43).

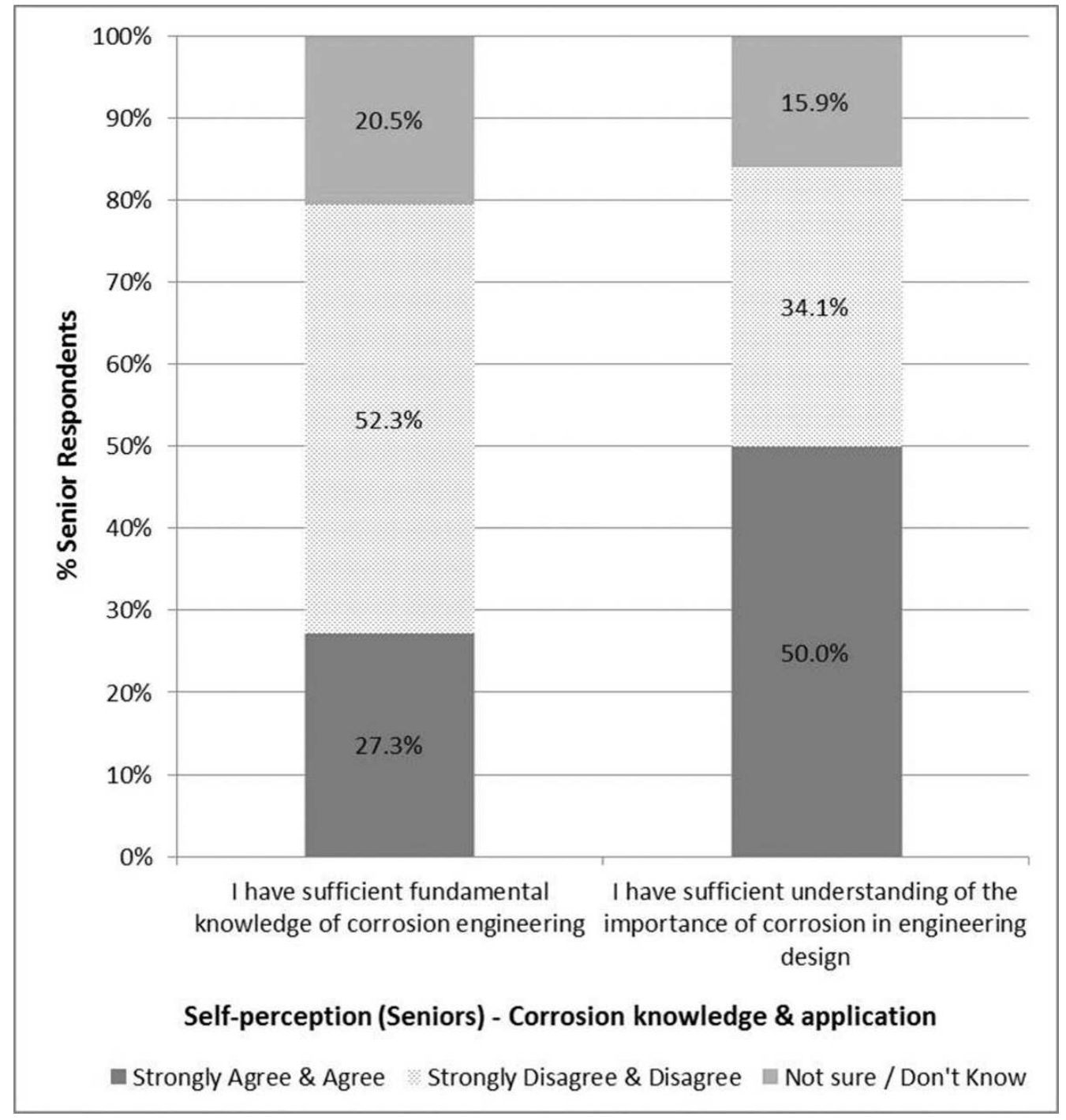

Figure 1: Self-perception - Competence in corrosion (Senior participants).

corrosion, the subjective data was compared to the objective quiz scores.

Most participants disagreed that they have sufficient fundamental knowledge of corrosion engineering (senior 52.3\%; sophomore 90\%) (Figure 1 and 2). In Lim (2012), academia (faculty, lab instructors) and 
030 Educ. Res.

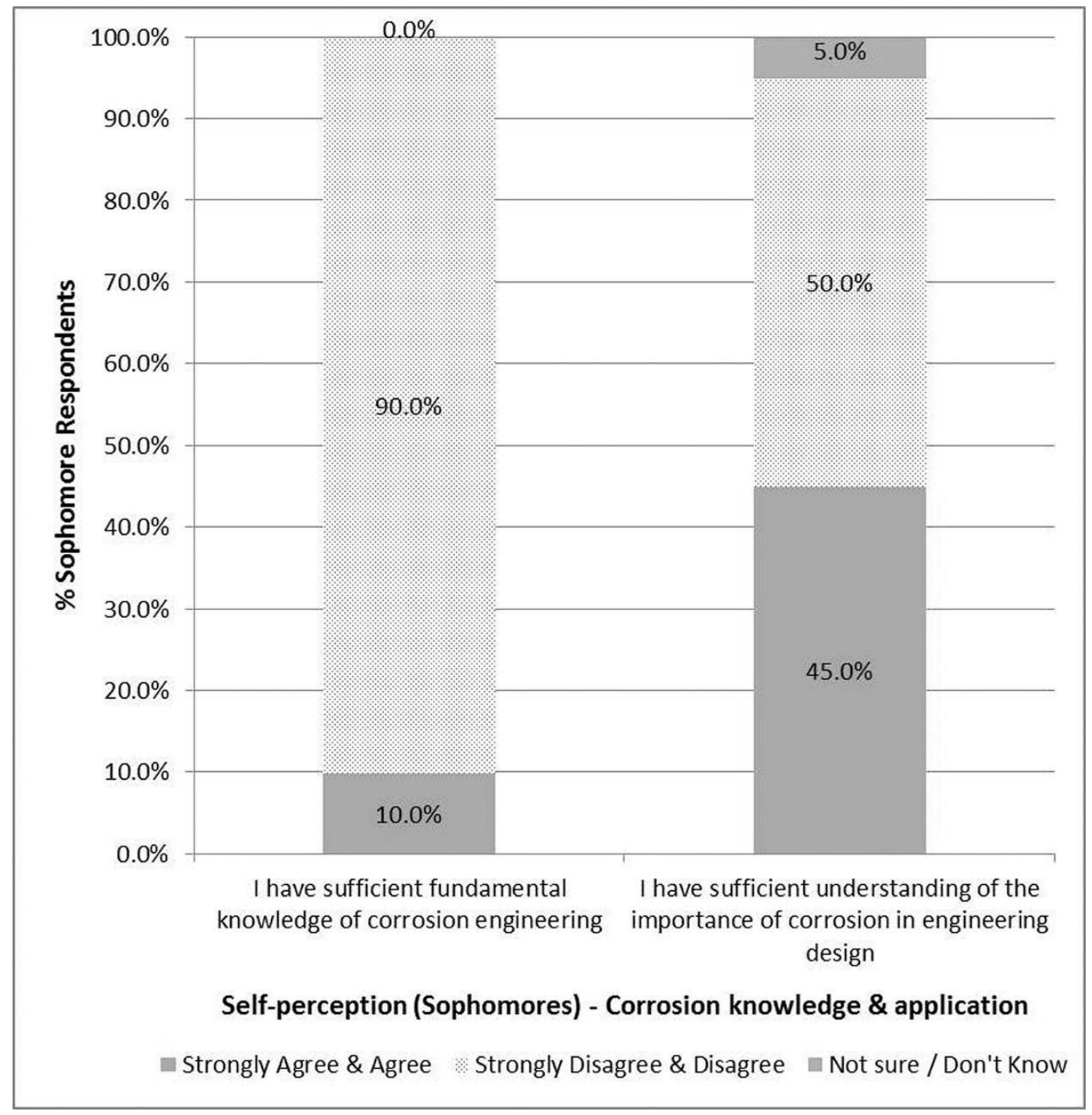

Figure 2: Self-perception - Competence in corrosion (Sophomore participants).

Industry participants were interviewed on their perceptions of a similar construct: engineering students' competence in corrosion. In this study, the students' selfperception was consistent with the academia/industry view that the former lacked fundamental knowledge of corrosion engineering. On the ability to apply corrosion concepts in design, more seniors agreed that they have sufficient understanding of the importance of corrosion in engineering design (50\%) compared to sophomores $(45 \%)$. Interestingly, participants from both levels had a higher positive perception of own application ability (SA and $A$ : senior $50 \%$; sophomore $45 \%$ ) than theoretical knowledge in corrosion (SA and A: senior 27.3\%; sophomore $10 \%$ ). This may be due to the students' experience with the engineering problem solving process. While design models differ based on disciplines, their common activities include problem identification, ideation, evaluation, and iteration that are carried out within phases starting from conceptual to preliminary and detailed design. For example, material selection with corrosion considerations or assigning tolerances to materials/parts can be considered as design refinement activities in the detailed design phase (Sobek II and Jain, 2004). The participants would have completed courses that explicitly taught engineering problem solving processes such as Introduction to Engineering or Fundamentals of Engineering in the Petroleum Industry. Moreover, the seniors would be in enrolled in Engineering Design Project I or II. Hence as novice engineers, participants would be familiar with the engineering problem solving process and have greater confidence in their ability to carry out the activities (application) even though they may not have an extensive repository of corrosion knowledge to draw from. 


\section{PART \#1 (LO1: corrosion mechanism and forms of corrosion in different environments)}

Q.1. Corrosion is the deterioration of a material by a reaction with its..
a) alloys
b) applied force
c) environment
d) atoms

Q.3. Which one of the following half reaction is an oxidation (corrosion)?
a) $\mathrm{Fe}^{3+}+3 e^{-} \rightarrow \mathrm{Fe}$
b) $\mathrm{Fe} \rightarrow \mathrm{Fe}^{2+}+2 e^{-}$
c) $\mathrm{Fe}^{2+}+2 e^{-} \rightarrow \mathrm{Fe}$
d) $2 \mathrm{H}^{+}+2 e^{-} \rightarrow \mathrm{H}_{2}$ (gas)

PART \#3 (LO3: identifying, monitoring, prevention and mitigation of corrosion.)

Q.18. The ..technique is the best known and simplest of all corrosion monitoring techniques
a) Weight Loss
b) Electrical Resistance
c) Linear Polarization Resistance
d) all

Q.19. Which one can be used as coating of steel pipe (as barrier film)?
a) $\mathrm{Ti}$
b) $\mathrm{Zn}$
c) $\mathrm{Au}$
d) all

Figure 3: Quiz questions 1, 3, 18-19.

Table 9: Quiz scores*

\begin{tabular}{lcc}
\hline $\begin{array}{l}\text { Learning objectives (LOs): The students should be able to demonstrate } \\
\text { knowledge and understanding of }\end{array}$ & Senior & Sophomore \\
\hline LO 1: corrosion mechanism and forms of corrosion in different environments. & $47.0 \%$ & $39.4 \%$ \\
LO 2: importance of corrosion in engineering design for petroleum industry. & $56.4 \%$ & $40.8 \%$ \\
LO 3: identifying, monitoring, prevention and mitigation of corrosion. & $40.0 \%$ & $33.0 \%$ \\
*AV quiz score obtained as \% of correct answers for 20 questions based on 44 seniors and 20 sophomores. \\
\hline
\end{tabular}

When compared to the self-perception results, the average quiz scores were consistent as seniors (48.1\%) scored $9.8 \%$ higher than the sophomores (38.3\%). When the average quiz scores were compared by question, sophomores scored slightly higher for four questions belonging to LO 1 and LO 3 (Figure. 3). Although the seniors scored higher for all three learning objectives, the largest difference compared to the sophomores was in LO 2 - application in design (seniors higher by 15.6\%) (Table 9) The smallest difference was for LO 3 prevention methods (seniors higher by $7 \%$ ). This may be because most corrosion prevention methods are part of common knowledge and hence the information is more accessible to the sophomores.

\section{Need to raise awareness of corrosion importance}

In the final interview question, participants were asked whether there is a need to increase engineering students' awareness of corrosion importance and to explain their views. Most held the positive view and suggested ways to increase awareness that are discussed in the next section. A minority held the view there was no need to increase awareness based on the following main reasons:

- $\quad$ Other engineering topics are more important.

- Corrosion knowledge needed by field workers rather than students.

- $\quad$ Corrosion experts are available.

- Solutions to corrosion problem are already available in the industry.

- Corrosion is not relevant to their future work in the petroleum industry.

In summary, findings on engineering undergraduates' awareness of corrosion importance showed that firstly, there is a need to reinforce the interdisciplinary nature of corrosion particularly among sophomores to improve understanding of corrosion importance in engineering 
032 Educ. Res.

Table 10: Suggestions to raise awareness of corrosion importance (ranked by importance)

\begin{tabular}{ll}
\hline Senior & Sophomore \\
1. Integrate corrosion content in & 1. Organize courses, lectures, \\
existing courses. & seminars, workshops on corrosion. \\
2. Organize lectures, seminars, & 2. Change corrosion course status \\
workshops on corrosion. & to a required course. \\
$\begin{array}{ll}\text { 3. Change corrosion course status to } & \text { 2. Integrate corrosion content in } \\
\text { a required course or a major elective. } & \text { existing courses. }\end{array}$ \\
\hline
\end{tabular}

work. Secondly, most participants in this study $(90 \%$ and above) would graduate as Mechanical, Petroleum, and Chemical engineers (Table 3 ) and the ability to manage corrosion at work is expected in the practice of these disciplines. Yet, reasons such as "Corrosion is not relevant to their future work in the petroleum industry" and "[Corrosion is] not relevant to major" were given for not focusing on the study of corrosion. Hence, there is a need to integrate more corrosion content in existing courses to improve undergraduates' knowledge of basic corrosion mechanisms, application in design, and prevention methods that would be needed by engineers at work.

\section{CONCLUSIONS AND RECOMMENDATIONS}

\section{Summary of results}

This study compared the awareness of corrosion importance between senior and sophomore engineering undergraduates in terms of three constructs (a) Preferred level of corrosion instruction; (b) Understanding of corrosion importance in engineering work; and (c) Competence in corrosion. The assumptions held for the constructs are discussed here in light of the findings.

For level of corrosion instruction, it was assumed that participants who regard corrosion as important would prefer a required corrosion engineering course and disagree with the statements that a few lectures on corrosion are needed and other engineering topics are more important than corrosion. However, most participants (sophomores and seniors)

$$
\text { preferred an elective corrosion engineering }
$$
course; and

- Agreed that a few lectures on corrosion are needed and other engineering topics are more important than corrosion.

The lack of support for this assumption suggests that there is still room for enhancing students' awareness of corrosion importance.

For understanding of corrosion importance in engineering work, it was assumed that participants who regard corrosion as important would select all majors or at least Chemical, Mechanical and Petroleum engineering majors as requiring corrosion knowledge and disagree that only corrosion engineers need to know about corrosion. It found that

- Chemical, Mechanical and Petroleum were selected by most participants (both levels) as majors that Require corrosion knowledge;

- Most participants disagreed that only corrosion engineers need to know about corrosion.

While this assumption was supported, the findings indicated that sophomores need to have greater understanding of corrosion importance in engineering work.

For competence in corrosion, it was assumed that compared to sophomores, more seniors would self-report having sufficient fundamental knowledge of corrosion and understanding of corrosion in engineering design (application), and score higher in the quiz than sophomores. It was found that compared to sophomore participants,

- More seniors agreed they have sufficient knowledge of corrosion engineering and understanding of the importance of corrosion in design; and

- $\quad$ The seniors' average quiz scores were higher.

Although the findings supported the assumption that seniors have a higher level of competence (perceived and actual) in corrosion compared to sophomores, the average quiz score for seniors was disappointingly low at $48.1 \%$. When on average, seniors answered fewer than half the 20 questions correctly; it implies that more needs to be done to improve undergraduates' knowledge of corrosion.

\section{Suggestions for raising awareness of corrosion importance}

Based on the findings, several suggestions for increasing student awareness of corrosion importance are provided such as integrating corrosion in existing courses and organizing courses, lectures, seminars, workshops on corrosion (Table 10). Particularly, the suggestion on change corrosion course status needed some clarification due to the terminology: a required course is a compulsory 
course for students from all five programs. The corrosion course content is expected to be broad with reference to a wide range of concepts and application in different engineering disciplines. A major elective is not a compulsory course. It is offered regularly every semester or year for students from specific programs. Hence, the course content is expected to be narrow with regard to concepts and applications specific to each engineering discipline.

The suggestion to change corrosion course status also raises the possibility of introducing two corrosion courses: (a) a basic course on Corrosion Science for sophomores as a required course; and (b) an advanced course on Corrosion Engineering for juniors/seniors as a major elective. While similar to CHEG416, this advanced course would have several versions such as Corrosion for Mechanical / Chemical / Petroleum / Electrical Engineers. Each course version would focuses on corrosion concepts and applications specific to that engineering discipline. For example, a Corrosion for Chemical and Petroleum Engineers course would focus on corrosion risks associated with chemical refining processes, corrosion kinetics, and pipeline integrity. It would cover corrosion management topics such as control of environmental corrosion, determination of optimum inhibitors, and use of biocides. In contrast, a Corrosion for Mechanical and Electrical Engineers course would focus on failure analysis due to corrosion of materials, and materials development (structural and coatings). It would cover topics such as interaction between corrosion and other failure mechanisms, failure due to creep as part of design concerns, use of automated corrosion detection and monitoring systems, development of corrosion rate predictors and sensors (Maleque and Salit, 2013).

Finally, to effectively integrate corrosion in existing courses, it is necessary to collaborate with instructors. A special interest group (SIG) could be formed comprising faculty (internal and external to the university) who teach engineering and science courses (such as Chemistry I/II). The inclusion of Chemistry instructors in the SIG could help develop teaching strategies that reinforce the link between basic Chemistry concepts taught in freshman year with topics in Corrosion Science. For example, Chemistry II course topics include the process of oxidation or reduction (redox - electron transfer reactions) for extracting metallic/non-metallic elements from their ores. This can be linked to engineering since the reverse process is corrosion. Also, the electrochemical process taught in Chemistry II can be linked to cathodic protection which is a process to protect metals from corrosion by using another metal as a sacrificial anode to protect the main structural material (Chang and Goldsby, 2015).

Based on the second co-author's experience, instructors of courses such as Material Science and
Senior Design do not refer explicitly to corrosion in teaching the curriculum since the students are assumed to have some background knowledge of corrosion which may not be a valid assumption. The opportunity for conversation between the SIG members could lead to improved pedagogical approaches that make the implicit explicit. In other words, the assumption of pre-existing corrosion knowledge in undergraduates should not be held.

Instead, the role of corrosion in relevant engineering course topics should be explicitly articulated with specific examples. This would not only bridge the gap between what students should know and what they actually do know about corrosion but also reinforce the transfer of knowledge between engineering courses.

\section{Future research}

The authors acknowledge that this study has limitations particularly, the limited sample source and size (at individual and institutional levels) that may not be representative of the entire sophomore and senior student population at the university nor all engineering universities in the Middle East region. However, these limitations do not detract from the value of the findings and naturally form the basis for future research directions.

In future research, the following modifications in methodology are suggested: (a) expand sample size to beyond 64, with equal numbers for senior and sophomore groups to ensure a better representative sample of the student population; (b) widen sample source to include female undergraduates, equal representation of all engineering programs and other engineering universities in the Arabian Gulf region; (c) pre-determine a specific proportion of senior participants who graduated from the CHEG416 course in the sample. Their quiz scores could be used as a benchmark to compare with scores of those who have not taken the course. Future research can expand on the current project scope by conducting longitudinal studies (using snapshot or cohort study designs) for tracking developmental changes in students' corrosion knowledge at sophomore, senior years and beyond; extending to corrosion knowledge gained and utilized by alumni engineers at work. The findings could be utilized to modify course curricula to better meet specific learning objectives.

\section{ACKNOWLEDGEMENTS}

The authors acknowledge the invaluable feedback provided by Dr. Bruce R. Palmer (Adjunct Professor) from the Department of Chemical and Biological Engineering, 
Colorado School of Mines, on the early draft of this manuscript.

\section{REFERENCES}

Abduh M (2011). The 50 Major Engineering Failures (1977-2007) Parts 1-5 Retrieved 29 September, 2011, from http://abduh137.wordpress .com/2008/04/25/the-50-major-engineering-failures-1977-2007-part$1 /$

ADNOC (2011). HSE Codes of Practice Retrieved 7 June, 2017, from http://adnoc-ae.ueuo.com/contentbd28.html?newid=136andmid=136

Ahmad Z (2006). Principles of Corrosion Engineering and Corrosion Control. Oxford: Butterworth-Heinemann.

Al Hashem A (2011). Corrosion in the Gulf Cooperation Council (GCC) states: Statistics and figures. Paper presented at the Corrosion UAE, Abu Dhabi, UAE.

Botes A (2015). Oil and Gas Reality Check: A Look at the Top Issues Facing Oil and Gas Sector Retrieved 4 June, 2017, from https://www2.deloitte.com/content/dam/Deloitte/global/Documents/E nergy-and-Resources/gx-er-oil-and-gas-reality-check-2015.pdf

Brondel D, Edwards R, Hayman A, Hill D, Mehta S, Semerad T (1994). Corrosion in the oil industry. Oilfield Review. 6: 4-18.

Capcis Limited (2001). Review of corrosion management for offshore oil and gas processing Offshore Technology Report (pp. 1-76). Manchester, UK Health and Safety Executive.

Chang R, Goldsby K (2015). Chemistry (12th ed.). Columbus, OH: McGraw-Hill Education.

Department of Municipality Affairs (2014). EHS: Introduction Retrieved 30 August, 2016, from http://www.adm.gov.ae/en/menu/index.aspx? TWVudUIEPTExNiZtbnU9UHJp

Donati M (2016). Cost cutting 'top priority' for oil and gas sector Retrieved 4 June, 2017, from https:/www.cips.org/supplymanagement/news/2016/february/cost-cutting-top-priority-for-oiland-gas-sector/

Driscoll D (2011). Introduction to Primary Research: Observations, Surveys, and Interviews. In C Lowe, P Zemliansky (Eds.), Writing Spaces: Readings on Writing (1st ed., Vol. 2, pp. 153-174). South Carolina: Parlor Press.

Engineering Council (2011). Guidance on Risk for the Engineering Profession (1st ed., pp. 1-8). London, UK: The Engineering Council.

Ernst and Young Limited (2016). The impact of decreasing oil prices on the GCC RHC market (1st ed., pp. 16). Dubai, UAE: Ernst and Young Global Limited.

Fessler R (2008). Pipeline Corrosion (1st ed., pp. 1-78). Washington, DC., US: Pipeline and Hazardous Materials Safety Administration, Office of Pipeline Safety.

Hays G (2015). Corrosion Awareness Day April 24, 2015 Retrieved 21 August, 2016, from https://www.fsb.unizg.hr/hdzama/150211 Corrosion_Awareness_Day.pdf

Ismail M, Zin, RM, Ismail MA, Yatim JM, Omar W (2008). Awareness among Professionals in Malaysian Construction Industries on Reinforcement Corrosion Prevention and Protection. Malaysian J. Civil Engineering. 20: 200-210.
Kermani M, Harrop D (1996). The impact of corrosion on oil and gas industry. SPE Production and Facilities. 11: 186-190.

Lim HL (2012). Assessing level and effectiveness of corrosion education in the United Arab Emirates. Intl. J. Corrosion. 2012: 110. doi: $10.1155 / 2012 / 785701$

Maleque MA, Salit MS (2013). Materials Selection and Design (1st ed.). Singapore: Springer Singapore.

Morgan DL (1997). Focus Groups as Qualitative Research (2nd ed. Vol. 16). Thousand Oaks, CA: Sage Publications.

Morsi KM, Al Key A (1993). Corrosion Prompts Replacement of Abu Dhabi Gas-Gathering System Retrieved 6 June, 2017, from http://www.ogj.com/articles/print/volume-91/issue-43/in-thisissue/pipeline/corrosion-prompts-replacement-of-abu-dhabi-gasgathering-system.html

NACE International (2016). IMPACT Breaks New Ground in the Study of Corrosion Management Retrieved 4 June, 2017, from http://impact.nace.org/

NACE International (2017). Corrosion Failures: Sinopec Gas Pipeline Explosion Retrieved 5 June, 2017, from https://www.nace.org/ CORROSION-FAILURES-Sinopec-Gas-Pipeline-Explosion.aspx

National Society of Professional Engineers (2016). NSPE Code of Ethics for Engineers Retrieved 30 August, 2016, from https://www.nspe.org/ resources/ethics/code-ethics

Offshore Energy Today (2013). Cormorant Alpha Shutdown Costs \$10 Mln Per Day (UK) Retrieved 6 June, 2017, from http://www.offshore energytoday. com/cormorant-alpha-shutdown-costs-10-mln-per-dayuk/

Ozturk F, Deveci T, Gunister E, Simmons R J (2015). Innovative Instructional Strategies for Teaching Materials Science in Engineering. In HL Lim (Ed.), Handbook of Research on Recent Developments in Materials Science and Corrosion Engineering Education (1st ed., pp. 100-117). Hershey, PA: IGI Global.

Pickard A (2007). Research Methods in Information. London: Facet Publishing.

Sastri VS (2015). Challenges in Corrosion: Costs, Causes, Consequences, and Control (1st ed.). Hoboken, NJ: Wiley.

Sobek II DK., Jain VK (2004, June). The Engineering Problem-Solving Process: Good for Students? Paper presented at the 2004 American Society for Engineering Education Annual Conference and Exposition, Salt Lake City, Utah.

The Guardian (2011). BP to pay out $\$ 25 \mathrm{~m}$ for 200,000 -gallon Alaska oil spill in 2006 Retrieved 5 June, 2017, from https://www.theguardian. com / environment /2011/may/04/bp-25m-north-slope-oil-spill

The Statistics Portal (2017). Average annual OPEC crude oil price from 1960 to 2017 (in U.S. dollars per barrel) Retrieved 4 June, 2017, from https://www.statista.com/statistics/262858/change-in-opeccrude-oil-prices-since-1960 


\section{Appendix 1: Corrosion quiz}

\section{PART \#1 (LO1: corrosion mechanism and forms of corrosion in different environments)}

Q1). Corrosion is the deterioration of a material by a reaction with its....
a) alloys
b) applied force
c) environment
d) atoms

Q2). Corrosion is time ...... and .......process.
a) independent
b) independent
c) dependent
reversible
Irreversible
reversible
d) dependent irreversible

Q3). Which one of the following half reaction is an oxidation (corrosion)?

a) $\mathrm{Fe}^{3+}+3 e^{-} \rightarrow \mathrm{Fe}$

b) $\mathrm{Fe} \rightarrow \mathrm{Fe}^{2+}+2 e^{-}$

c) $\mathrm{Fe}^{2+}+2 e^{-} \rightarrow \mathrm{Fe}$

d) $2 \mathrm{H}^{+}+2 e^{-} \rightarrow \mathrm{H}_{2}$ (gas)

Q4). The most common type of corrosion in smooth surface of metals is
a) erosion-corrosion
b)crevice
c) uniform
d)All

Q5). The most localized and hiding form of corrosion is
a) pitting
b) biocorrosion
c) intergranular
d) stress

Q6). Dissimilar metal's corrosion by electrochemical process is called as ..................... corrosion
a) stress
b) intergranular
c) galvanic
d) pitting

Q7). The corrosion rate can be controlled by changing the ........
a) temperature
b) acidity
c) humidity
d) All

Q8). Which one of the following is corrosive for metals
a) $\quad \mathrm{CO}_{2}$
b) $\quad \mathrm{H}_{2} \mathrm{~S}$
c) Chloride Brine
d) All

Q9). The acceptable corrosion rate for steel is
a) less than $0.5 \mathrm{~mm} /$ year
b) $0.1-0.5 \mathrm{~cm} /$ year
c) $1 \mathrm{~mm} /$ year
d) $5 \mathrm{~mm} /$ year

\section{PART \#2 (LO2: importance of corrosion in engineering design for petroleum industry)}

Q1). Corrosion related failures constitute of

failures experienced in the oil and gas industry.
a) Less than $5 \%$
b) $5-15 \%$
c) $16-24 \%$
d) $25 \%$ and above

Q2)...........corrosion caused by the impingement of a high velocity turbulent flow on a surface of pipe.
a) Erosion
b) Pitting
c) Galvanic
d) Stress

Q3). Corrosion may cause piping, vessels and tanks to become
a) less brittle
b) more ductile
c) more brittle
d) more strong

Q4). Annual corrosion cost range is .............. of the each nation's gross national product (GNP).
a) $0.1-0.5 \%$
b) $0.5-1 \%$
c) $1-5 \%$
d) Less than $1 \%$

Q5). Corrosion problems occur in the petroleum industry in
a) transportation
and
b)production
c) refinery operations
d) all

Q6). The deterioration of metal due to contact with hydrogen sulfide $\left(\mathrm{H}_{2} \mathrm{~S}\right)$ and moisture is called damaging to drill pipe.
a) sweet
b)sour
c) both
d) none

\section{PART \#3 (LO3: identifying, monitoring, prevention and mitigation of corrosion)}

Q1). Corrosion in high-pressure flowing wells that produce pipeline oil can be combated by
a) coated tubing
b) inhibitors
c) Cr-Steel alloys
d) all

Q2). Which one of the following method should be used to prevent corrosion?
a) Sacrificial Anode
b) low $\mathrm{pH}$ solution
c) Salted water
d)all

Q3). The ...........technique is the best known and simplest of all corrosion monitoring techniques
a) Weight Loss
b) Electrical Resistance
c) Linear
Polarization
d) all

Q4). Which one can be used as coating of steel pipe (as barrier film)?
a) $\mathrm{Ti}$
b) $\mathrm{Zn}$
c) $\mathrm{Au}$
d) all

Q5).............are chemicals that are used to protect the surface of metals used in oil and gas industries to prevent corrosion.
a) Acidic solutions
b) $\mathrm{CO}_{2}$
c) $\mathrm{H}_{2} \mathrm{~S}$
d) Inhibitors corrosion which is the most 